\title{
KOMPETENSI USAHA MIKRO KECIL \& MENENGAH (UMKM) \\ KOTA BANDUNG DALAM MENGAHADAPI PERSAINGAN \\ MASYARAKAT EKONOMI ASEAN (MEA)
}

\section{THE COMPETENCE OF MICRO SMALL \& MEDIUM BUSINESSES (UMKM) IN BANDUNG CITY TO FACE THE COMPETITION IN ASEAN ECONOMIC COMMUNITY (MEA)}

\author{
Tini Martini, Janadi Rammelsbergi Thamrin \\ Politeknik Komputer Niaga LPKIA \\ niemartini@yahoo.com
}

\begin{abstract}
ABSTRAK
Penelitian ini bertujuan untuk mengetahui gambaran umum kompetensi, kesiapan UMKM dalam bersaing dalam era MEA dengan kompetensi yang dimiliki, serta kompetensi apa saja yang harus dimiliki UMKM Kota Bandung. Penelitian ini menggunakanteknik analisis korelasi Pearson Product Momentyaitu dengan meneliti kompetensi dan daya saing UMKM. Penelitian ini menggunakan 80 orang responden UMKM Kota Bandung.Hasil penelitian menunjukkan bahwa kompetensi hubungan antar manusia termasuk dalam kategori tinggi, kompetensi pemasaran adalah yang paling rendah. Adapun korelasi antara kompetensi dan persaingan bisnis adalah sebesar 41,3\%. Serta kompetensi yang harus dimiliki adalah kompetensi hubungan antar manusia, kompetensi konseptual, dan kompetensi pemasaran.

Kata kunci: kompetensi, persaingan, UMKM
\end{abstract}

\section{ABSTRACT}

This study aims to unveil the general description of competence and the readiness of UMKM (Micro, Small and Medium-sized Enterprises) to compete in the era of MEA (ASEAN Economic Community), and what competencies should be possessed by the UMKMin Bandung. This research uses Pearson Product Moment correlation analysis technique which examines the competencies and competitiveness of UMKM. This study involves 80 respondents of UMKM in Bandung. The results show that the human relations competency rankswithin high category, while marketing competency is at the lowest rank. The correlation between competence and business competition is 41.3\%. Meanwhile, the competencies that must be possessedarehuman relations competencies, conceptual competencies, and marketing competencies.

Keywords: competence, competition, UMKM

\section{PENDAHULUAN}

Usaha Mikro Kecil \& Menengah (UMKM) merupakan salah satu pelaku ekonomi yang terbukti tangguh menghadapi kondisi perekonomian yang kurang baik, hal ini dapat terlihat pada saat terjadinya krisis ekonomi 1998 dimana perusahaan-perusahaan besar banyak yang kolaps. Akan tetapi UMKM dengan keterbatasan modalnya mampu bertahan menghadapi krisis ekonomi. Pada saat ini kondisi perekonomian Indonesia secara nasional tengah mengalami perlambatan yang ditandai dengan menurunnya tingkat konsumsi masyarakat secara umum. Kenaikan harga bbm dan listrik ditengarai sebagai salah satu faktor yang dapat menghambat perkembangan UMKM, karena para pelaku UMKM sangat menggantungkan keberlangsungan usahanya pada dua komponen energi tersebut.

Suatu negara sangat membutuhkan keberadaan UMKM dalam kegiatan perekonomiannya. Berdasarkan data Badan Pusat Statistik, seluruh usaha kecil menengah memberikan kontribusi dalam PDB sebesar 57,9 persen dan kontribusi penyerapan tenaga Jurnal Penelitian Pendidikan 
kerja 97,2 persen. "Sedangkan di kawasan ASEAN, lebih dari 96 persen perusahaan di ASEAN adalah UMKM dan kontribusi terhadap PDB sebesar 30-50 persen. Apabila kita bandingkan, UMKM ternyata mampu membuka lapangan kerjabaru bagi 9,6 juta orang, sedangkanusaha besar hanya mampu membukalapangan kerja baru bagi 55.760 orang. Selain itu UMKM memberikan kontribusi terhadap ekspor non migas nasional sebesar 19,9\%. Hal tersebut menunjukkan bahwa UMKM memegang peranan penting dalam perekonomian suatu negara karena memberikan kontribusi pemasukan yang besar untuk negara. Selain itu pula UMKM dapat menjadi pemecah permasalah pengangguran yang terjadi di Indonesia.

Minat masyarakat untuk menjadi pelaku UMKM tiap tahunnya selalu mengalami peningkatan. Berdasarkan data yang didapat dari Badan Pusat Statistik diketahui bahwa pada tahun 2012 jumlah pelaku UMKM di Indonesia adalah sebanyak 56.534.592sedangkan pada tahun 2013 jumlah UMKM di Indonesia mengalami peningkatan sebesar $2,41 \%$ yaitu menjadi sebanyak 57.895.721. Pemerintah provinsi Jawa Barat pada saat ini sedang berusaha untuk meningkatkan jumlah UMKM yaitu dengan diluncurkannya Program Penciptaan 100.000 Wirausaha Baru Provinsi Jawa Barat pada bulan Juli 2014. Program ini merupakan program jangka panjang, dimana 100.000 wirausaha baru ini ditargetkan dapat tercapai dalam jangka waktu empat tahun yaitu dari tahun 2014-2018. Pada akhirnya, program ini diharapkan dapat meningkatkan kesejahteraan masyarakat Jawa Barat, mengurangi jumlah pengangguran, membuka lapangan kerja baru, dan menekan tingkat kemiskinan di Provinsi Jawa Barat.

Masyarakat Ekonomi ASEAN (MEA) merupakan sistem perdagangan bebas atau free trade antara negara-negara anggota ASEAN yang baru saja dimulai tepatnya pada tanggal 1 Januari 2016. Sesungguhnya MEA bertujuan untuk melakukan pengubahan ASEAN menjadi suatu kawasan makmur, stabil dan sangat bersaing dalam perkembangan ekonomi yang berlaku adil dan dapat mengurangi kesenjangan dan kemiskinan sosial ekonomi. Berlakunya MEA telah menimbulkan banyak kekhawatiran pada para pelaku UMKM. Para pelaku UMKM sangat khawatir jika mereka tidak dapat bersaing dengan pengusaha dari negara ASEAN lainnya dan ditambah dengan keadaan perekonomian yang tidak stabil pada saat ini ditakutkan dapat memicu terjadinya suatu krisis perekonomian. Dalam bahasa Mandarin kata krisis sendiri adalah wei $j i$, dimana setiap kata itu mempunyai makna khusus. Wei berasal dari kata wei xian yang artinya bahaya. Di dalam krisis itu ada bahaya. Sebaliknya, ji berasal dari kataji hui yang artinya kesempatan. Sehingga, dalam krisis ada bahaya sekaligus ada kesempatan. Sesungguhnya apabila para pelaku UMKM dapat berfikir secara positif, maka akan terdapat banyak kesempatan yang bisa diraih dengan diberlakukannya MEA.

Pada saat ini terdapat beberapa persoalan yang dihadapi oleh para pelaku UMKM di Indonesia, yaitu: kurangnya pengetahuan sehingga produk yang dihasilkan tidak mampu bersaing secara luas; para pelaku UMKM belum bisa memasarkan produknya secara luas padahal penduduk Indonesia sendiri adalah pasar yang sangat potensial; kurangnya modal sehingga usaha mereka tidak dapat berkembang; kurang 
memanfaatkan teknologi secara maksimal sehingga kegiatan produksi masih terbatas; belum adanya kesadaran dari para pelaku UMKM untuk mendaftarkan hak paten baik itu dari segi merek, logo, maupun formula; serta tidak mempunyai network yang luas.

Zimmerer \& Scarborough (2002:41) menyatakan bahwa kompetensi inti (core competencies) adalah seperangkat unik kemampuan yang dikembangkan dalam daerah-daerah operasional kunci, seperti mutu, layanan, inovasi, pembangunan tim, fleksibilitas, cepat tanggap, dan lainnya yang memungkinkan melebihi pesaing. Kompetensi inti ini akan menjadi dasar dari keunggulan kompetitif perusahaan dan biasanya bertahan cukup lama. Kompetensi yang dimiliki para pelaku UMKM tentunya merupakan modal yang sangat berharga baik itu untuk menghasilkan produk yang berkualitas, memasarkan produk, penguasaan teknologi, maupun untuk berkomunikasi dengan pelanggan, dll.

Setiap pelaku usaha tentunya menginginkan agar usahanya dapat sustainable, oleh karena itu mereka harus dapat bersaing dengan pelaku usaha lainnya. Agar dapat bersaing dengan negara-negara ASEAN lainnya dalam Masyarakat Ekonomi ASEAN (MEA) maka para pelaku UMKM harus memiliki berbagai macam kelebihan. UMKM harus menjaga dan meningkatkan daya saing sebagai industri kreatif dan inovatif. Selain itu UMKM juga harus meningkatkan standar, desain dan kualitas produk agar sesuai dengan ketentuan ASEAN, misalnya para pelaku UMKM bisa melihat pada ketentuan ISO 26000 untuk green product. Berdasarkan berbagai macam kompetensi yang ada tentunya para pelaku UMKM harus memiliki kompetensi dasar yang akan menjadi modal untuk dapat bersaing dalam menghadapi MEA.

\section{UMKM}

Berdasarkan UU No.20 Tahun 2008 tentang UMKM, Bab I (Ketentuan Umum) Pasal 1 dinyatakan bahwa Usaha Mikro Kecil \& Menengah (UMKM) adalah usaha produktif milik perseorangan dan/ atau badan usaha perseorangan yang memenuhi kriteriaUMKM sebagaimana diatur dalam UU tersebut. UMKM adalah unit usaha yang memiliki nilai aset paling banyak Rp.50.000.000,- atau dengan hasil penjualan tahunan paling besar Rp.300.000.000,- (Tambunan, 2009:16).

UMKM tidak dapat berdiri dengan sendirinya. Upaya untuk mengembangkan dan memajukan para pelaku UMKM bisa dilakukan oleh berbagai unsur yang ada di masyarakat baik secara sendiri-sendiri maupun dengan cara bekerjasama. Adapun unsur-unsur yang dapat berkiprah dalam memajukan para pelaku UMKM tersebut antara lain: pemerintah baik pusat maupun daerah, institusi pendidikan (perguruan tinggi), lembaga bank yang mempunyai tujuan untuk menyalurkan kreditnya sekaligus sebagai lembaga intermediasi dalam bidang keuangan, dan lembaga swadaya masyarakat (LSM) yang mengkhususkan bergerak dalam pembinaan UKM (Moko, 2008:390-391).

Menurut Nitisusastro

(2012:38-39) dengan segala keterbatasannya, ternyata UMKM memiliki sejumlah kekuatan, yaitu: (1) Mengembangkan kreativitas usaha baru, (2) Melakukan inovasi, (3) Ketergantungan usaha besar terhadap usaha kecil, (4) Daya tahan terhadap krisis.UMKM akan tetap mampu tumbuh dan berkembang namun jika diperhatikan lebih seksama lagi, maka kelemahan UMKM adalah tidak akan 
mampu mengembangkan usahanya jika tidak mendapatkan bantuan kucuran dana sebagai modal dalam berkompetisi, oleh karena itu kelemahan-kelemahan yang berupa kurangnya permodalan, kemampuan manajerial, persaingan yang kurang sehat akan mengakibatkan ruang lingkup usaha menjadi terbatas.(Suci, 2017:56)

Terdapat sejumlah persoalan/ rintangan yang umum dihadapi oleh UMKM di berbagai daerah, yaitu modal kerja/ investasi, kesulitan-kesulitan dalam pemasaran, distribusi dan pengadaan bahan baku dan input lainnya, keterbatasan akses ke informasi mengenai peluang pasar, keterbatasan pekerja dengan keahlian tinggi (kualitas SDM rendah) dan kemampuan teknologi, biaya transportasi dan energi yang tinggi, keterbatasan komunikasi, biaya tinggi akibat prosedur administrasi dan birokrasi yang kompleks, khususnya dalam pengurusan izin usaha dan ketidakpastian akibat peraturanperaturan dan kebijaksanaan-kebijaksanaan ekonomi yang tidak jelas atau tidak menentu arahnya (Tambunan, 2009:75).

\section{KOMPETENSI}

Kompetensi merupakan karakteristik yang menonjol bagi seseorang dan menjadi caracara berperilaku dan berfikir dalam segala situasi, dan berlangsung dalam periode waktu yang lama (Spencer dan Spencer dalam Uno, 2007: 63). Kompetensi terbentuk dari sebuah proses belajar maupun pengalaman yang relatif lama. Hal ini merupakan sebuah nilai tambah dari seseorang yang mendukungnya sebagai modal utama agar dapat bersaing terhadap kompetitor. Seorang wirausahawan harus memiliki keunggulan yang merupakan kekuatan bagi dirinya dan usahanya serta harus memperbaiki kelemahannya agar menghasilkan keunggulan bersaing bagi usahanya (Suryana, 2013: 90).

Menurut Scarborough, dalam Heru (2009: 38) terdapat sembilan kompetensi yang harus dimiliki wirausaha yaitu: (1) Kenali bisnis anda, seorang wirausaha dalam melakukan kegiatan usaha harus mengetahui dengan jelas bisnis apa yang dilakukan sekarang dan prospek di masa depan; (2) Mengetahui dasar manajemen bisnis, pengetahuan dasar manajemen bisnis merupakan pengetahuan yang harus dan benar-benar dimiliki oleh wirausaha agar unggul; (3) Memiliki modal yang cukup, wirausaha adalah manajer dalam arti memilki kemampuan dalam mengelola usaha; (4) Mengatur keuangan secara efisien, wirausaha yang unggul ketika mampu mengelola keuangan dengan efektif; (5) Mengatur waktu secara efisien, wirausahawan harus mampu mengelola waktu dengan baik. Adakalanya produk, pemesanan, job dan kegiatan di luar bisnis cukup tinggi sejalan dengan banyaknya kolega; (6) Mengelola orang lain, sejalan dengan meningkatnya bisnis, hubungan antara karyawan, dengan orang lain, pihak luar, masyarakat semakin tinggi; (7) Memuaskan pelanggan dengan menyediakan produk berkualitas tinggi, wirausaha yang unggul mengajarkan bahwa barang dan jasa yang berkualitas tinggi sangat penting dalam mempertahankan persaingan; (8) Mengetahui bagaimana cara bersaing, persaingan yang sehat, mampu menjaga kemitraan sangat dibutuhkan bagi kelangsungan bisnis di masa depan; (9) Membuat aturan/ pedoman yang jelas tersurat, aturan yang jelas dan formal sangat dibutuhkan bagi pertanggung jawaban kegiatan dan kelangsungan hidup bisnis.

Menurut Heru (2009:41), disebutkan juga bahwa kompetensi wirausaha terbagi menjadi 
tujuh, antara lain: (1) Kompetensi hubungan antar manusia, (2) Kompetensi teknik, (3) Kompetensi marketing, (4) Kompetensi keuangan, (5) Kompetensi konseptual, (6) Kompetensi dalam pengambilan keputusan, (7) Kompetensi dalam mengatur waktu.

\section{PERSAINGAN}

Pesaing adalah perusahaan yang menghasilkan atau menjual barang atau jasa yang sama atau mirip dengan produk yang kita tawarkan (Kasmir, 2013: 279). Persaingan berasal dari bahasa Inggris yaitu competition yang berarti persaingan itu sendiri atau kegiatan bersaing, pertandingan, kompetisi. Sedangkan dalam kamus manajemen, persaingan adalah usaha-usaha dari dua belah pihak atau lebih perusahaan yang masingmasing berkegiatan, memperoleh pesanan dengan menawarkan harga atau syarat yang paling menguntungkan (Maribun, 2003: 276).

Agar mampu menghadapi persaingan, UMKM harus dapat mengidentifikasi seluruh pesaing yang ada. Hal ini perlu dilakukan agar kita dapat mengetahui secara utuh kondisi pesaing. Identifikasi pesaing ini meliputi: (1) Jenis produk yang ditawarkan, (2) Melihat besarnya pasar yang dikuasai (market share) pesaing, (3) Identifikasi peluang dan ancaman, (4) Identifikasi keunggulan dan kelemahan.(Kasmir, 2013:282-283)

Menurut Hendro (2011:388) secara garis besar ada banyak cara pembeda yang sering digunakan oleh perusahaan tetapi sebagian besar perusahaan menggunakan empat cara sederhana dalam membedakan sebuah bisnis dengan bisnis pesaing, yaitu: (1) Lebih baik (better than), (2) Lebih baru (newer than), (3) Lebih cepat (faster than), (4) Lebih murah (lower price than.)
Adapun yang menjadi tujuan dari penelitian yang telah dilakukan ini adalah untuk mengetahui: (1) Bagaimana gambaran umum kompetensi UMKM Kota Bandung? (2) Apakah dengan kompetensi yang dimiliki, UMKM Kota Bandung sudah siap menghadapi persaingan di era MEA? (3) Kompetensi apa sajakah yang harus dimiliki UMKM dalam menghadapi MEA?

\section{METODE PENELITIAN}

Metode penelitian yang digunakan dalam penelitian ini bersifat deskriptif dan verifikatif. Metode deskriptif bertujuan untuk menggambarkan sifat sesuatu yang tengah berlangsung pada saat penelitian dilakukan dan untuk memeriksa sebab-sebab dari suatu gejala tertentu. Dalam penelitian ini bertujuan untuk memperoleh gambaran tentang kompetensi UMKM Kota Bandung dalam menghadapi persaingan Masyarakat Ekonomi ASEAN.

Penelitian verifikatif bertujuan untuk menguji kebenaran suatu hipotesis yang dilaksanakan melalui pengumpulan data di lapangan di mana dalam penelitian ini akan diuji apakah terdapat pengaruh antara kompetensi UMKM terhadappersaingan Masyarakat Ekonomi ASEAN.

Menurut Nazir dalam Riduwan \& Kuncoro (2008:37) populasi adalah wilayah gerneralisasi yang terdiri dari objek atau subjek yang menjadi kuantitas dan karakteristik tertentu yang ditetapkan oleh peneliti untuk dipelajari dan kemudian ditarik kesimpulannya. Populasi dalam penelitian ini adalah UMKM yang terdapat di Kota Bandung. Berdasarkan data yang diperoleh dari Kadin Kota Bandung diketahui bahwa jumlah UMKM Kota Bandung yang terdaftar adalah sebanyak 405 UMKM. 
Teknik pengambilan sampel menggunakan simple random sampling yaitu cara pengambilan sampel dari anggota populasi dengan menggunakan acak tanpa memperhatikan strata (tingkatan) dalam anggota populasi tersebut. Karena penelitian ini bersifat sosial, maka taraf kesalahan ditetapkan sebesar 10\%.

Berdasarkan perhitungan menggunakan simple random sampling, maka jumlah sampel dari penelitian ini adalah:

$$
\begin{aligned}
\mathrm{n}=\frac{\mathrm{N}}{\mathrm{N} d^{2}+} & \frac{405}{\mathrm{n}}=\frac{405}{1+(405)\left(0,1^{2}\right)} \\
\mathrm{n} & =5,05 \\
\mathrm{n} & =80,20 \\
\mathrm{n} & \approx 80
\end{aligned}
$$

Teknik pengumpulan data, mengacu pada cara apa yang digunakan untuk memperoleh data yang diperlukan dalam penelitian. Kaitannya dalam hal tersebut, serta dengan melihat konsep analitis dari penelitian ini, maka teknik pengumpulan data yang digunakan dapat melalui kombinasi secara langsung atau tidak.

Data yang diperoleh dalam penelitian ini didapatkan dengan menggunakan teknik sebagai berikut: (1) Angket (kuesioner), yaitu teknik pengumpulan data melalui penyebaran seperangkat daftar pertanyaan tertulis kepada responden yang menjadi anggota sampel penelitian; (2) Wawancara, yaitu pengumpulan data atau informasi dengan mengajukan pertanyaan-pertanyaan kepada pihak-pihak yang berkepentingan dan mengetahui dengan jelas permasalahan yang dikemukakan yaitu mengenai kompetensi UMKM dan persaingan usaha; (3) Observasi, yaitu dilakukan dengan meninjau dan melakukan pengamatan langsung terhadap objek yang diteliti; (4) Studi pustaka, yaitu pengumpulan informasi yang berhubungan dengan teori-teori yang ada kaitannya dengan permasalahan yang diteliti.

Data yang diperoleh melalui pengisian kuesioner kemudian diolah menggunakan teknik analisis Korelasi Pearson Product Moment (PPM), yang berguna untuk mengetahui derajat hubungan antara variabel bebas (independent) dengan variabel terkait (dependent). Menurut Riduwan \& Kuncoro (2008:62) rumus yang digunakan untuk mengetahui korelasi PPM adalah sebagai berikut:

$r_{X Y}=\frac{n(\Sigma X Y)-(\Sigma X) \cdot(\Sigma Y)}{\sqrt{\left\{n \cdot \Sigma X^{2}-(\Sigma X)^{2}\right\} \cdot\left\{n \cdot \Sigma Y^{2}-(\Sigma Y)^{2}\right\}}}$

Hubungan antar variabel terdiri dari dua macam yaitu menjadi hubungan/pengaruh yang positif dan hubungan dan pengaruh yang negatif. Hubungan/pengaruh $\mathrm{X}$ dan Y dikatakan positif apabila kenaikan (penurunan) $\mathrm{X}$ pada umumnya diikuti oleh kenaikan (penurunan) Y. Ukuran yang dipakai untuk mengetahui kuat atau tidaknya hubungan antara $\mathrm{X}$ dan $\mathrm{Y}$ disebut koefisien (r). Nilai koefisien paling sedikit -1 dan paling besar $1(1 \leq \mathrm{r} \leq 1)$, artinya jika:

$r=1$, hubungan $\mathrm{X}$ dan $\mathrm{Y}$ sempurna dan positif (mendekati 1, hubungan sangat kuat dan positif)

$\mathrm{r}=-1$, hubungan $\mathrm{X}$ dan $\mathrm{Y}$ sempurna dan negatif (mendekati -1 , hubungan sangat kuat dan negatif)

$\mathrm{r}=0$, hubungan $\mathrm{X}$ dan $\mathrm{Y}$ lemah sekali dan tidak ada hubungan.

Penentuan koefisien korelasi (r) dalam penelitian ini menggunakan koefisien korelasi pearson(Pearson's product moment), karena penelitian ini memiliki lebih dari satu prediktor. $\mathrm{X}$ dikatakan mempengaruhi Y, 
jika berubahnya nilai $\mathrm{X}$ akan menyebabkan adanya perubahan nilai $\mathrm{Y}$, artinya naik turunnya $\mathrm{X}$ akan membuat nilai $\mathrm{Y}$ juga naik turun, dengan demikian nilai $\mathrm{Y}$ ini akan bervariasi. Namun nilai Y bervariasi tersebut tidak semata-mata disebabkan oleh X, karena masih ada faktor lain yang menyebabkannya.

Besar kecilnya sumbangan variabel $\mathrm{X}$ terhadap $\mathrm{Y}$ dapat ditentukan dengan rumus koefisien determinan sebagai berikut.

$\mathrm{KP}=\mathrm{r}^{2} \times 100 \%$

Dimana:

$\mathrm{KP}=$ Nilai koefisien determinan

$\mathrm{R}=$ Nilai koefisien korelasi

(Riduwan \& Kuncoro, 2008:62)

Tabel 1

Interpretasi Hasil Penelitian

\begin{tabular}{lc}
\hline \multicolumn{1}{c}{ Kategori } & Rentang Rata-rata \\
\hline Tinggi & $4,0-5,0$ \\
\hline Cukup tinggi & $3,0-3,9$ \\
\hline Kurang & $2,0-2,9$ \\
\hline Rendah & $1,0-1,9$ \\
\hline
\end{tabular}

Sumber: Sambas Ali Muhidin (2007)

Pengujian signifikansi yang berfungsi apabila peneliti ingin mencari makna generalisasi dari hubungan variabel $\mathrm{X}$ terhadap Y, maka hasil korelasi PPM tersebut diuji dengan uji signifikansi sebagai berikut: Hipotesis:

$\mathrm{Ha}$ : variabel $\mathrm{X}$ berhubungan secara signifikan dengan variabel $Y$

Ho : variabel $\mathrm{X}$ tidak berhubungan secara signifikan dengan variabel Y

\section{HASIL DAN PEMBAHASAN}

1. Kompetensi Usaha Mikro Kecil \&

\section{Menengah (UMKM)}

Variabel kompetensi UMKM dalam penelitian ini diukur berdasarkan kompetensi hubungan antar manusia $\left(\mathrm{X}_{1}\right)$, teknik $\left(\mathrm{X}_{2}\right)$, pemasaran $\left(\mathrm{X}_{3}\right)$, keuangan $\left(\mathrm{X}_{4}\right)$, konseptual $\left(\mathrm{X}_{5}\right)$, mengambil keputusan $\left(\mathrm{X}_{6}\right)$, dan mengatur waktu $\left(\mathrm{X}_{7}\right)$. Ke tujuhkompetensi untuk mengukur kompetensi UMKM tersebut, kemudian dijabarkan ke dalam 48butir angket, dan diperoleh deskripsi data sebagai berikut.

Tabel 2

Tanggapan Responden Terhadap Kompetensi UMKM

\begin{tabular}{clc}
\hline Alternatif Jawaban & \multicolumn{1}{c}{ Kategori } & Persentase \\
\hline 1 & Tidak pernah & $9.5 \%$ \\
\hline 2 & Jarang & $10.4 \%$ \\
\hline 3 & Kadang-kadang & $28.0 \%$ \\
\hline 4 & Sering & $21.7 \%$ \\
\hline 5 & Selalu & $30.5 \%$ \\
\hline \multicolumn{2}{c}{ Jumlah } & $100 \%$ \\
\hline & Rata-rata & 3,52 \\
\hline
\end{tabular}

Sumber: Jawaban responden

Tabel di atas menunjukkan bahwa pilihan responden untuk setiap pernyataan angket pada variabel kompetensi UMKM tersebar pada lima alternatif jawaban, yaitu selalu (5) dengan persentase $30,5 \%$, sering (4) sebesar $21,7 \%$,kadang-kadang (3) sebesar 28,0\%, jarang (2) sebesar 10,4\%, dan tidak pernah (1) sebesar 9,5\%, Temuan penelitian ini juga menunjukkan bahwa secara umum responden pengusaha UMKM di Kota Bandung memiliki kemampuan/kompetensi UMKM yang cukup tinggi. Hal ini ditunjukkan oleh rata-rataskor data sebesar 3,52 yang ada pada kategori cukup tinggi (lihat tabel interpretasi hasil penelitian).

Selanjutnya terkait dengan gambaran 
dimensi-dimensi yang membentuk sebagai berikut.

kompetensi UMKM dapat terlihat pada data

Tabel 3

Tanggapan Responden Terhadap Kompetensi Hubungan Antar Manusia

\begin{tabular}{clc}
\hline Alternatif Jawaban & \multicolumn{1}{c}{ Kategori } & Persentase \\
\hline 1 & Tidak pernah & $5.0 \%$ \\
\hline 2 & Jarang & $7.1 \%$ \\
\hline 3 & Kadang-kadang & $14.2 \%$ \\
\hline 4 & Sering & $19.6 \%$ \\
\hline 5 & Selalu & $54.2 \%$ \\
\hline \multicolumn{2}{c}{ Jumlah } & $100 \%$ \\
\hline \multicolumn{2}{c}{ Rata-rata } & 4,11 \\
\hline
\end{tabular}

Sumber: Jawaban responden

Tabel di atas menunjukkan bahwa pilihan responden untuk setiap pernyataan angket pada kompetensi hubungan antar manusia tersebar pada lima alternatif jawaban, yaitu selalu (5) dengan persentase 54,2\%, sering (4) sebesar 19,6\%,kadang-kadang (3) sebesar $14,2 \%$, jarang (2) sebesar 7,1\%, dan tidak pernah (1) sebesar 5\%, Temuan penelitian ini juga menunjukkan bahwa secara umum responden pengusaha UMKM di Kota Bandung memiliki kemampuan/kompetensi hubungan antar manusia yang tinggi. Hal ini ditunjukkan oleh rata-rataskor data sebesar 4,11 yang ada pada kategori tinggi (lihat tabel interpretasi hasil penelitian).

Kompetensi hubungan antar manusia adalah kompetensi wirausaha yang berhubungan dengan kemampuan menjaga, membangun, mengembangkan, hubungan baik dengan orang, serta pihak yang berkepentingan dengan aktivitas perusahaan, seperti dengan: rekan kerja, karyawan, penyalur barang, pemasok bahan, investor, kreditur, masyarakat (Heru, 2009:41). Kompetensi hubungan antar manusia ini meliputi berkomunikasi dengan baik kepada konsumen, tidak pernah membuat konsumen kecewa, cepat tanggap (fast response) dalam melayani konsumen, tetangga tidak terganggu dengan aktivitas usaha, membayar tagihan supplier dengan tepat waktu, dan usaha yang dijalani menarik perhatian investor.

Tabel 4

Tanggapan Responden Terhadap Kompetensi Teknik

\begin{tabular}{clc}
\hline Alternatif Jawaban & \multicolumn{1}{c}{ Kategori } & Persentase \\
\hline 1 & Tidak pernah & $4.6 \%$ \\
\hline 2 & Jarang & $7.5 \%$ \\
\hline 3 & Kadang-kadang & $26.7 \%$ \\
\hline 4 & Sering & $30.8 \%$ \\
\hline 5 & Selalu & $30.4 \%$ \\
\hline \multicolumn{2}{c}{ Jumlah } & $100 \%$ \\
\hline \multicolumn{2}{c}{ Rata-rata } & 3,75 \\
\hline
\end{tabular}

Sumber: Jawaban responden 
Tabel di atas menunjukkan bahwa pilihan responden untuk setiap pernyataan angket pada kompetensi teknik tersebar pada lima alternatif jawaban, yaitu selalu (5) dengan persentase $30,8 \%$, sering (4) sebesar 30,46\%,kadang-kadang (3) sebesar 26,7\%, jarang (2) sebesar 7,5\%, dan tidak pernah (1) sebesar $4,6 \%$, temuan penelitian ini juga menunjukkan bahwa secara umum responden pengusaha UMKM di Kota Bandung memiliki kemampuan/kompetensi teknik yang cukup tinggi. Hal ini ditunjukkan oleh rata-rataskor data sebesar 3,75 yang ada pada kategori cukup tinggi (lihat tabel interpretasi hasil penelitian).

Kompetensi teknik adalah kompetensi wirausaha yang berhubungan dengan teknik, cara, bahan serta tenaga kerja yang menghasilkan berang dan jasa yang dihasilkan perusahaan (Heru, 2009:41). Kompetensi teknik ini meliputiproduk/ jasa yang dihasilkan tidak mengalami kegagalan, konsumen puas terhadap produk/ jasa, kegiatan usaha dilakukan dengan efektif dan efisien, menyelesaikan orderan dari konsumen dengan tepat waktu, merasa puas dengan peralatan yang dimiliki, dankaryawan mengikuti prosedur kerja dengan benar.

Tabel 5

Tanggapan Responden Terhadap Kompetensi Pemasaran

\begin{tabular}{|c|l|c|}
\hline Alternatif Jawaban & \multicolumn{1}{|c|}{ Kategori } & Persentase \\
\hline 1 & Tidak pernah & $22.9 \%$ \\
\hline 2 & Jarang & $13.8 \%$ \\
\hline 3 & Kadang-kadang & $23.8 \%$ \\
\hline 4 & Sering & $17.9 \%$ \\
\hline 5 & Selalu & $21.7 \%$ \\
\hline & \multicolumn{1}{|c|}{ Jumlah } & $100 \%$ \\
\hline & Rata-rata & 3,02 \\
\hline
\end{tabular}

Sumber: Jawaban responden

Tabel di atas menunjukkan bahwa pilihan responden untuk setiap pernyataan angket pada kompetensi pemasaran tersebar pada lima alternatif jawaban, yaitu selalu (5) dengan persentase $30,8 \%$, sering (4) sebesar 30,46\%,kadang-kadang (3) sebesar 26,7\%, jarang (2) sebesar 7,5\%, dan tidak pernah (1) sebesar 4,6\%, Temuan penelitian ini juga menunjukkan bahwa secara umum responden pengusaha UMKM di Kota Bandung memiliki kemampuan/kompetensi pemasaran yang cukup tinggi. Hal ini ditunjukkan oleh rata-rataskor data sebesar 3,02 yang ada pada kategori cukup tinggi (lihat tabel interpretasi hasil penelitian).

Kompetensi pemasaran adalah kompetensi wirausaha yang berkaitan dengan kemampuan wirausaha di bidang pemasaran produk (Heru, 2009:41). Kompetensi pemasaran ini meliputiproduk/jasa dikenal oleh konsumen, menggunakan sosial media dalam kegiatan pemasaran, memiliki follower/ friends yang banyak dalam sosial media, melakukan interaksi dengan konsumen dalam sosial media, menggunakan market place dalam memasarkan produk/jasa, dan jumlah penjualan sesuai dengan target yang sudah ditetapkan. 
Tabel 6

Tanggapan Responden Terhadap Kompetensi Keuangan

\begin{tabular}{clc}
\hline Alternatif Jawaban & \multicolumn{1}{c}{ Kategori } & Persentase \\
\hline 1 & Tidak pernah & $9.2 \%$ \\
\hline 2 & Jarang & $19.6 \%$ \\
\hline 3 & Kadang-kadang & $30.0 \%$ \\
\hline 4 & Sering & $9.2 \%$ \\
\hline 5 & Selalu & $32.1 \%$ \\
\hline & Jumlah & $3,35 \%$ \\
\hline
\end{tabular}

Sumber: Jawaban responden

Tabel di atas menunjukkan bahwa pilihan responden untuk setiap pernyataan angket pada kompetensi keuangan tersebar pada lima alternatif jawaban, yaitu selalu (5) dengan persentase $32,1 \%$, sering (4) sebesar 9,2\%,kadang-kadang (3) sebesar 30,0\%, jarang (2) sebesar 19,6\%, dan tidak pernah (1) sebesar 9,2\%, Temuan penelitian ini juga menunjukkan bahwa secara umum responden pengusaha UMKM di Kota Bandung memiliki kemampuan/kompetensi keuangan yang cukup tinggi. Hal ini ditunjukkan oleh rata-rataskor data sebesar 3,35 yang ada pada kategori cukup tinggi (lihat tabel interpretasi hasil penelitian).

Kompetensi keuangan adalah kompetensi wirausaha dalam mengelola keuangan, terutama mencari sumber pendanaan yang paling murah, menggunakan dan menginvestasikan dana yang menguntungkan, membuat anggaran yang tepat dan membagi laba atas keuntungan usaha dengan memuaskan semua pihak yang berkepentingan (Heru, 2009:41). Kompetensi keuangan ini meliputimembuat laporan keuangan, perhitungan keuangan, modal usaha, modal usaha digunakan untuk keperluan pribadi,dana tambahan dari investor/ bank, dan memberikan keuntungan (bagi hasil) berdasarkan kesepakatan awal kepada investor. Modal adalah faktor yang mempunyai peran cukup penting dalam proses produksi, karena modal diperlukan ketika pengusaha hendak mendirikan perusahaan baru atau untuk memperluas usaha yang sudah ada, tanpa modal yang cukup maka akan berpengaruh terhadap kelancaran usaha, sehingga akan mempengaruhi pendapatan yang diperoleh (Dewi, 2014:579).

Tabel 7

Tanggapan Responden Terhadap Kompetensi Konseptual

\begin{tabular}{clc}
\hline Alternatif Jawaban & \multicolumn{1}{c}{ Kategori } & Persentase \\
\hline 1 & Tidak pernah & $16.7 \%$ \\
\hline 2 & Jarang & $11.7 \%$ \\
\hline 3 & Kadang-kadang & $33.3 \%$ \\
\hline 4 & Sering & $15.4 \%$ \\
\hline 5 & Selalu & $22.9 \%$ \\
\hline & Jumlah & $100 \%$ \\
\hline
\end{tabular}

Sumber: Jawaban responden 
Tabel di atas menunjukkan bahwa pilihan responden untuk setiap pernyataan angket pada kompetensi konseptual tersebar pada lima alternatif jawaban, yaitu selalu (5) dengan persentase $22,9 \%$, sering (4) sebesar 15,4\%,kadang-kadang (3) sebesar 33,3\%, jarang (2) sebesar $11,7 \%$, dan tidak pernah (1) sebesar $16,7 \%$. Temuan penelitian ini juga menunjukkan bahwa secara umum responden pengusaha UMKM di Kota Bandung memiliki kemampuan/kompetensi konseptual yang cukup tinggi. Hal ini ditunjukkan oleh rata-rataskor data sebesar 3,16 yang ada pada kategori cukup tinggi (lihat tabel interpretasi hasil penelitian).
Kompetensi konseptual adalah kompetensi yang dimiliki oleh wirausahawan yang berhubungan dengan kemampuan untuk membuat konsep kegiatan, event, produk yang baik. Konsep tersebut apabila dijalankan dapat berhasil (Heru, 2009:41). Kompetensi konseptual ini meliputi mengeluarkan produk baru minimal satu tahun sekali, produk mengikuti trend/perkembangan zaman, kemasan produk/tempat usaha menarik perhatian konsumen,tidak meniru produk lain,mengikuti kegiatan pelatihan, danmelakukan riset untuk mengetahui keinginan konsumen.

Tabel 8

Tanggapan Responden Terhadap Kompetensi Mengambil Keputusan

\begin{tabular}{|c|l|c|}
\hline Alternatif Jawaban & \multicolumn{1}{|c|}{ Kategori } & Persentase \\
\hline 1 & Tidak pernah & $8.3 \%$ \\
\hline 2 & Jarang & $9.6 \%$ \\
\hline 3 & Kadang-kadang & $45.0 \%$ \\
\hline 4 & Sering & $22.1 \%$ \\
\hline 5 & Selalu & $15.0 \%$ \\
\hline & \multicolumn{1}{|c|}{ Jumlah } & $100 \%$ \\
\hline & Rata-rata & 3,26 \\
\hline
\end{tabular}

Sumber: Jawaban responden

Tabel di atas menunjukkan bahwa pilihan responden untuk setiap pernyataan angket pada kompetensi mengambil keputusan tersebar pada lima alternatif jawaban, yaitu selalu (5) dengan persentase $15,0 \%$, sering (4) sebesar 22,1\%, kadang-kadang (3) sebesar 45,0\%, jarang (2) sebesar 9,6\%, dan tidak pernah (1) sebesar $8,3 \%$. Temuan penelitian ini juga menunjukkan bahwa secara umum responden pengusaha UMKM di Kota Bandung memiliki kemampuan/ kompetensi mengambil keputusan yang cukup tinggi. Hal ini ditunjukkan oleh ratarataskor data sebesar 3,26 yang ada pada kategori cukup tinggi (lihat tabel interpretasi hasil penelitian).

Kompetensi mengambil keputusan adalah kompetensi yang dimiliki oleh wirausahawan yang berkaitan dengan kemampuan untuk mengambil keputusan dengan tepat (Heru, 2009:41). Kompetensi ini meliput imengambil resiko, keputusan yang ambil disukai karyawan, dapat memprediksi pasar (selera konsumen), keputusan yang diambil selalu tepat dan menguntungkan, keputusan selalu didukung oleh investor, dan membeli bahan baku sebelum mengalami kenaikan harga. 
Tabel 9

Tanggapan Responden Terhadap Kompetensi Mengatur Waktu

\begin{tabular}{clc}
\hline \begin{tabular}{c} 
Alternatif Jawaban \\
\cline { 1 - 3 }
\end{tabular} & Kategori & Persentase \\
\hline 2 & Tidak pernah & $2.9 \%$ \\
\hline 3 & Jarang & $5.4 \%$ \\
\hline 4 & Kadang-kadang & $22.5 \%$ \\
\hline 5 & Sering & $30.8 \%$ \\
\hline & Selalu & $38.3 \%$ \\
\hline & Jumlah & $3,90 \%$ \\
\hline
\end{tabular}

Sumber: Jawaban responden

Tabel di atas menunjukkan bahwa pilihan responden untuk setiap pernyataan angket pada kompetensi mengatur waktu tersebar pada lima alternatif jawaban, yaitu selalu (5) dengan persentase $15,0 \%$, sering (4) sebesar 22,1\%, kadang-kadang (3) sebesar 45,0\%, jarang (2) sebesar 9,6\%, dan tidak pernah (1) sebesar 8,3\%. Temuan penelitian ini juga menunjukkan bahwa secara umum responden pengusaha UMKM di Kota Bandung memiliki kemampuan/kompetensi mengatur waktu yang cukup tinggi. Hal ini ditunjukkan oleh rata-rataskor data sebesar 3,96 yang ada pada kategori cukup tinggi (lihat tabel interpretasi hasil penelitian).

Kompetensi mengatur waktu adalah kompetesi yang dimiliki oleh wirausahawan yang berhubungan dengan kemampuan mengatur waktu dengan efisien (Heru, 2009:41). Kompetensi ini meliputi mempunyai jadwal kerja, barang diproduksi dengan tepat waktu, mampu membuat skala prioritas, tidak pernah membuang-buang waktu, mengerjakan pekerjaan sesuai dengan jadwal yang telah dibuat, dan konsumen tidak perlu menunggu lama untuk melakukan pembelian produk/jasa.
Sekaitan dengan kompetensi UMKM di atas, secara empirik diperoleh informasi bahwa kompetensi hubungan antar manusia merupakan kompetensi yang dominan dimiliki dalam membentuk kompetensi UMKM di Kota Bandung. Rata-rata skornya adalah 4,11. Temuan ini sekaligus juga mengindikasikan bahwa kompetensi UMKM di Kota Bandung yang paling tinggi adalah kompetensi hubungan antar manusia, dibandingkan dengan kompetensi UMKM lainnya.

Sementara kompetensi terendah adalah kompetensi pemasaran. Rata-rata skornya sebesar 3,02, lebih kecil dibandingkan dengan rata-rata skor kompetensi UMKM lainnya. Temuan penelitian ini sekaligus juga mengindikasikan bahwa kompetensi pemasaran lebih rendah jika dibandingkan kompetensihubungan antar manusia, teknik, keuangan, konseptual, mengambil keputusan, mengatur waktu, dan persaingan bisnis.

Secara keseluruhan, temuan empirik tentang gambaran tingkat penguasaan kompetensi UMKM di Kota Bandung tampak pada tabel berikut. 
Tabel 10

Rata-rata Penguasaan Kompetensi UMKM di Kota Bandung

\begin{tabular}{|c|c|c|c|}
\hline No. & Kompetensi UMKM & Rata-rata & Kategori \\
\hline 1 & Hubungan antar manusia & 4.11 & Tinggi \\
\hline 2 & Teknik & 3.75 & Cukup Tinggi \\
\hline 3 & Pemasaran & 3.02 & Cukup Tinggi \\
\hline 4 & Keuangan & 3.35 & Cukup Tinggi \\
\hline 5 & Konseptual & 3.16 & Cukup Tinggi \\
\hline 6 & Mengambil keputusan & 3.26 & Cukup Tinggi \\
\hline \multirow[t]{2}{*}{7} & Mengatur waktu & 3.96 & Cukup Tinggi \\
\hline & Rata-rata & 3,52 & Cukup Tinggi \\
\hline
\end{tabular}

Sumber: Jawaban responden

\section{Persaingan Bisnis UMKM}

Variabel persaingan bisnisUMKM dalam penelitian ini diukur berdasarkan produk barang/jasa dapat diterima oleh konsumen, kualitas produk (barang/jasa) lebih bagus/ unggul dibandingkan kompetitor, produk (barang/jasa) dikenal oleh banyak orang, produk (barang/jasa) sudah terjual kepada konsumen yang berada di luar kota, produk (barang/jasa) yang ditawarkan lebih murah dibandingkan kompetitor, dan mempunyai anggaran khusus untuk melakukan kegiatan promosi. Ukuran-ukuran yang membentuk persaingan bisnis UMKM tersebut, diperoleh deskripsi data sebagai berikut.

Tabel 11

Tanggapan Responden Terhadap Persaingan Bisnis UMKM

\begin{tabular}{clc}
\hline \begin{tabular}{c} 
Alternatif Jawaban \\
\hline 1
\end{tabular} & \multicolumn{1}{c}{ Kategori } & Persentase \\
\hline 2 & Tidak pernah & $6.7 \%$ \\
\hline 3 & Jarang & $8.3 \%$ \\
\hline 4 & Kadang-kadang & $28.3 \%$ \\
\hline 5 & Sering & $27.5 \%$ \\
\hline & Selalu & $29.2 \%$ \\
\hline & Jumlah & $3,60 \%$ \\
\hline
\end{tabular}

Sumber: Jawaban responden

Tabel di atas menunjukkan bahwa pilihan responden untuk setiap pernyataan angket pada persaingan bisnis tersebar pada lima alternatif jawaban, yaitu selalu (5) dengan persentase $29,2 \%$, sering (4) sebesar 27,5\%, kadang-kadang (3) sebesar $28,3 \%$, jarang (2) sebesar 8,3\%, dan tidak pernah (1) sebesar $6,7 \%$. Temuan penelitian ini juga menunjukkan bahwa secara umum persaingan bisnis UMKM di Kota Bandung cukup tinggi. Hal ini ditunjukkan oleh rata- rataskor data sebesar 3,64 yang ada pada kategori cukup tinggi (lihat tabel interpretasi hasil penelitian).

\section{Kompetensi yang harus dimiliki UMKM}

Kompetensi yang harus dimiliki UMKM didapatkan dari pemeringkatan kompetensi UMKM yang terdiri dari kompetensi hubungan antar manusia, teknik, pemasaran, keuangan, konsepsitual, mengambil 
keputusan, dan mengatur waktu. yang kurang penting berdasarkan persepsi Penyusunan peringkat ini dilakukan dengan para pelaku UMKM, sehingga kita dapat cara mengurutkan kompetensi UMKM dari yang paling penting hingga kompetensi mengetahui kompetensi apa saja yang paling dibutuhkan UMKM.

Tabel 12

Kompetensi yang harus dimiliki UMKM

\begin{tabular}{clcc}
\hline \begin{tabular}{c} 
No. \\
\hline 1
\end{tabular} & \multicolumn{1}{c}{ Kompetensi UMKM } & Score & Persentase \\
\hline 2 & Hubungan antar manusia & 384 & $19,03 \%$ \\
\hline 3 & Teknik & 252 & $12,49 \%$ \\
\hline 4 & Pemasaran & Keuangan & 316 \\
\hline 5 & Konseptual & 268 & $15,66 \%$ \\
\hline 6 & Mengambil keputusan & 328 & $13,28 \%$ \\
\hline 7 & Mengatur waktu & 222 & $11 \%$ \\
\hline$\quad$ Jumlah & 248 \\
\hline
\end{tabular}

Sumber: Jawaban responden

Tebel di atas menunjukkan bahwa kompetensi yang yang paling dibutuhkan UMKM adalah kompetensi hubungan antar manusia yaitu sebesar 19,03\%, kemudian diikuti kompetisi konseptual yaitu sebesar $16,25 \%$, kompetensi pemasaran yaitu sebesar $15,66 \%$, kompetensi keuangan yaitu sebesar $13,28 \%$, kompetensi teknik yaitu sebesar $12,49 \%$, kompetensi mengatur waktu yaitu sebesar 12,29\%, dan yang terakhir adalah mengambil keputusan yaitu sebesar 11\%. Temuan ini menunjukkan bahwa kompetensi utama yang harus dimiliki para pelaku UMKM agar dapat bersaing di era MEA adalah kompetensi hubungan antar manusia.

Selanjutnya sekaitan pengaruh penguasaan kompetensi UMKM terhadap persaingan bisnis UMKM, dapat dijelaskan sebagai berikut. Secara empiris, hasil penelitian ini menginformasikan bahwa kompetensi UMKM memberikan pengaruh terhadap persaingan bisnis UMKM di Kota Bandung hal ini ditunjukkan oleh hasil penelitian bahwa besarnya koefisien determinasi yang diberikan oleh kompetensi UMKM terhadap persaingan bisnis sebesar 41,3\% Namun demikian persaingan bisnis ini tidak hanya dipengaruhi oleh kompetensi UMKM, ada faktor lain (epsilon) yang juga berpengaruh. Dengan demikian, hasil penelitian ini mengindikasikan bahwa semakin tinggi kompetensi UMKM yang dimiliki pengusaha, maka akan diikuti oleh semakin tingginya persaingan UMKM di Kota Bandung. Sehingga dapat diketahui bahwa UMKM Kota Bandung masih memerlukan peningkatan kompetensi agar dapat bersaing di era MEA.

Sedangkan untuk kompetensi yang harus dimiliki oleh UMKM, berdasarkan data yang diperoleh ternyata kompetensi hubungan antar manusia mendapatkan nilai yang paling besar yaitu 19,03\%, kemudian diikuti kompetisi konseptual yaitu sebesar 16,25\%, dan kompetensi pemasaran yaitu sebesar $15,66 \%$. Ketiga jenis kompetensi tersebut mempunyai pengaruh yang sangat penting bagi keberlangsungan usaha.

Pengusaha harus dapat menjalin hubungan yang baik dengan karyawan dan mitra kerja, 
seperti supplier maupun agen-agen yang membantu memasarkan produk, karena dapat dapat memberikan dampak hubungan yang baik dengan konsumen. Semakin kuat hubungan, semakin kecil atau semakin hubungan tersebut akan berakhir. Kualitas dari suatu hubungan yang terbina dengan baik, sangat membantu perusahaan untuk mengontrol masa depan dan kelangsungan hidup usahanya (Jasfar, 2009:163).

Organisasi bisnis akan berhasil mencapai tujuannya apabila mampu memenuhi keinginan konsumennya, sehingga mereka harus mampumenciptakan produk yang sesuai dengan keinginan konsumen. Pengembangan produk merupakan upaya perusahaan untuk memperbaiki, memodifikasi produk lama, maupun menciptakan produk baru yang bertujuan untuk mengikuti keinginan konsumen serta agar dapat memenuhi tuntutan pasar. (Yamit, 2011:34).

Pemasaran adalah suatu proses dimana seseorang atau kelompok dapat memenuhi kebutuhan dan keinginan konsumen melalui penciptaan, penawaran dan pertukaran barang dan jasa. Kepuasan yang dirasakan oleh konsumen, akan menimbulkan respon positif berupa terjadinya pembelian ulang dan menganjurkan konsumen lain agar membeli produk yang sama (Alma, 2007:5).

\section{SIMPULAN}

1. UMKM di Kota Bandung memiliki kemampuan/kompetensi hubungan antar manusia sebesar 4,11 yang ada pada kategori tinggi; kemampuan/kompetensi teknik sebesar 3,75 yang ada pada kategori cukup tinggi; kemampuan/ kompetensi pemasaran sebesar 3,02 yang ada pada kategori cukup tinggi; kemampuan/kompetensi keuangan sebesar 3,35 yang ada pada kategori cukup tinggi; kemampuan/kompetensi konseptual sebesar 3,16 yang ada pada kategori cukup tinggi; kemampuan/ kompetensi mengambil keputusan sebesar 3,26 yang ada pada kategori cukup tinggi; kemampuan/kompetensi mengatur waktu sebesar 3,96 yang ada pada kategori cukup tinggi.

2. Kompetensi UMKM memberikan pengaruh terhadap persaingan bisnis UMKM di Kota Bandung sebesar 41,3\%. Sehingga dapat diketahui bahwa UMKM Kota Bandung masih belum siap dalam menghadapi persaingan dalam era MEA.

3. Kompetensi yang harus dimiliki UMKM Kota Bandung adalah kompetensi hubungan antar manusia (19,03\%), kompetisi konseptual $(16,25 \%)$, serta kompetensi pemasaran $(15,66 \%)$.

\section{DAFTAR RUJUKAN}

Alma, B. (2007). Manajemen Pemasaran dan Pemasaran Jasa. Bandung: Alfabeta.

Dewi, P. M. (2014). Pengaruh Modal, Tingkat Pendidikan dan Teknologi Terhadap Pendapatan Usaha Mikro Kecil dan Menengah (UMKM) di Kawasan Imam Bonjol Denpasar Barat. Ekonomi Pembangunan Universitas Udayana Vol.3 No.12

Hendro. (2011). Dasar-Dasar Kewirausahaan: Panduan bagi Mahasiswa untuk Mengenal, Memahami, dan Memasuki Dunia Bisnis. Jakarta: Erlangga.

Heru, K. HC. R, (2009). Kewirausahaan Entrepreneurship Pendekatan Manajemen dan Praktik. Yogyakarta: Graha Ilmu.

Jasfar, F. (2009). Manajemen Jasa: Pendekatan Terpadu. Bogor: Ghalia Indonesia.

Kasmir. (2013). Kewirausahaan. Jakarta: PT Raja Grafindo Persada. 
Maribun, B. N. (2003). Kamus Manajemen. Jakarta: Pustaka Sinar Harapan.

Moko, A. P. (2008). Entrepreneurship: dalam Perspektif Kondisi Bangsa Indonesia.Bandung: Alfabeta.

Muhidin, S. A. (2007). Analisis Korelasi, Regresi dan Jalur dalam Penelitian. Bandung: CV Pustaka Setia.

Nitisusastro, M. (2012). Kewirausahaan dan Manajemen Usaha Kecil. Bandung: Alfabeta.

Riduwan., \& Kuncoro, E. A. (2008). Cara Menggunakan dan Memaknai Analisis Jalur (Path Analysis). Bandung: Alfabeta.

Suryana. (2013). Kewirausahaan: Pedoman Praktis, Kiat dan Proses Menuju Sukses. Jakarta: Salemba Empat

Tambunan, T. T. H. (2009). UMKM di Indonesia. Jakarta: Ghalia Indonesia.

Uno, H. B. (2007). Teori Motivasi dan Pengukurannya Analisis di Bidang Pendidikan. Jakarta: Bumi Aksara.

Yamit, Z. (2011). Manajemen Produksi dan Operasi. Yogyakarta: Ekonisia.

Suci, Y. R. (2017). Perkembangan UMKM (Usaha Mikro Kecil dan Menengah) di Indonesia. Jurnal Ilmiah Cano Ekonomos Vol 6 No 1 Januari 2017.51-58

Zimmerer, T W., \& Scarborough, N. M. (2002). Pengantar Kewirausahaan dan Manajemen Bisnis Kecil. Jakarta: Prenhallindo. 